a contribution from the

Department of Chemistry

University at Buffalo

State University of New York

Buffalo, NY 14260-3000

\title{
Formation of $\left[\operatorname{Pt}\left(\eta^{3} \text {-allyl)(TPPTS }\right)_{2}\right]^{+}$from Reaction of cis-Pt(Cl $)_{2}(\mathrm{TPPTS})_{2}$ with Alkenols in Water
}

by

Derrik S. Helfer, David S. Phaho

and Jim D. Atwood*

Supporting Information 


\section{Detailed NMR Discussion}

NMR spectra were recorded for each of the reaction solutions. ${ }^{31} \mathrm{P}\left\{{ }^{1} \mathrm{H}\right\}$ NMR was utilized in determining any changes that occurred to the starting Pt compound. ${ }^{1} \mathrm{H}$ NMR was utilized to detect any changes in the substrates and to calculate any percent conversion of products formed. The observed ${ }^{1} \mathrm{H}$ NMR of the starting substrates and products are given below:

(a) allyl alcohol: $\delta 5.77$ (m, $\left.\mathrm{CH}_{2}=\mathrm{CHCH}_{2} \mathrm{OH}, 1 \mathrm{H}\right), \delta 4.97\left(\mathrm{~m}, \mathrm{CH}_{2}=\mathrm{CHCH}_{2} \mathrm{OH}, 2 \mathrm{H}\right), \delta 3.88$ (d, $\mathrm{CH}_{2}=\mathrm{CHCH}_{2} \mathrm{OH}, 2 \mathrm{H}$ ).

(b) acetol: $\delta 2.01\left(\mathrm{~s}, \mathrm{CH}_{3} \mathrm{C}(\mathrm{O}) \mathrm{CH}_{2} \mathrm{OH}, 3 \mathrm{H}\right), \delta 4.20\left(\mathrm{~s}, \mathrm{CH}_{3} \mathrm{C}(\mathrm{O}) \mathrm{CH}_{2} \mathrm{OH}, 2 \mathrm{H}\right)$

(c) 3-buten-1-ol: $\delta 5.64$ (m, $\left.\mathrm{CH}_{2}=\mathrm{CHCH}_{2} \mathrm{CH}_{2} \mathrm{OH}, 1 \mathrm{H}\right), \delta 4.95$ (m, $\mathrm{CH}_{2}=\mathrm{CHCH}_{2} \mathrm{CH}_{2} \mathrm{OH}$, $2 \mathrm{H}), \delta 3.49\left(\mathrm{t}, \mathrm{CH}_{2}=\mathrm{CHCH}_{2} \mathrm{CH}_{2} \mathrm{OH}, 2 \mathrm{H}\right), \delta 2.08\left(\mathrm{q}, \mathrm{CH}_{2}=\mathrm{CHCH}_{2} \mathrm{CH}_{2} \mathrm{OH}, 2 \mathrm{H}\right)$.

(d) 2-buten-1-ol: $\delta 5.55\left(\mathrm{~m}, \mathrm{CH}_{3} \mathrm{CH}=\mathrm{CHCH}_{2} \mathrm{OH}, 1 \mathrm{H}\right), \delta 5.45\left(\mathrm{~m}, \mathrm{CH}_{3} \mathrm{CH}=\mathrm{CHCH}_{2} \mathrm{OH}, 1 \mathrm{H}\right)$, $\delta 3.80\left(\mathrm{~d}, \mathrm{CH}_{3} \mathrm{CH}=\mathrm{CHCH}_{2} \mathrm{OH}, 2 \mathrm{H}\right), \delta 1.49\left(\mathrm{~d}, \mathrm{CH}_{3} \mathrm{CH}=\mathrm{CHCH}_{2} \mathrm{OH}, 3 \mathrm{H}\right)$.

(e) 4-hydroxy-butan-2-one: $\delta 3.63\left(\mathrm{t}, \mathrm{CH}_{3} \mathrm{C}(\mathrm{O}) \mathrm{CH}_{2} \mathrm{CH}_{2} \mathrm{OH}, 2 \mathrm{H}\right), \delta 2.57$ (t, $\left.\mathrm{CH}_{3} \mathrm{C}(\mathrm{O}) \mathrm{CH}_{2} \mathrm{CH}_{2} \mathrm{OH}, 2 \mathrm{H}\right), \delta 2.02\left(\mathrm{~s}, \mathrm{CH}_{3} \mathrm{C}(\mathrm{O}) \mathrm{CH}_{2} \mathrm{CH}_{2} \mathrm{OH}, 3 \mathrm{H}\right.$ )

(f) $\underline{\text { 3-buten-2-ol: } \delta} 5.69\left(\mathrm{~m}, \mathrm{CH}_{3} \mathrm{CHOHCH}=\mathrm{CH}_{2}, 1 \mathrm{H}\right), \delta 4.97\left(\mathrm{~m}, \mathrm{CH}_{3} \mathrm{CHOHCH}=\mathrm{CH}_{2}, 2 \mathrm{H}\right)$, $\delta 4.11$ (quin, $\left.\mathrm{CH}_{3} \mathrm{CHOHCH}=\mathrm{CH}_{2}, 1 \mathrm{H}\right), \delta 1.02\left(\mathrm{~d}, \mathrm{CH}_{3} \mathrm{CHOHCH}=\mathrm{CH}_{2}, 3 \mathrm{H}\right)$.

(g) 4-penten-1-ol: $\delta 5.74\left(\mathrm{~m}, \mathrm{CH}_{2}=\mathrm{CHCH}_{2} \mathrm{CH}_{2} \mathrm{CH}_{2} \mathrm{OH}, 1 \mathrm{H}\right), \delta 4.88(\mathrm{~m}$, $\left.\mathrm{CH}_{2}=\mathrm{CHCH}_{2} \mathrm{CH}_{2} \mathrm{CH}_{2} \mathrm{OH}, 2 \mathrm{H}\right), \delta 3.43\left(\mathrm{t}, \mathrm{CH}_{2}=\mathrm{CHCH}_{2} \mathrm{CH}_{2} \mathrm{CH}_{2} \mathrm{OH}, 2 \mathrm{H}\right), \delta 1.92$ (q, $\mathrm{CH}_{2}=\mathrm{CHCH}_{2} \mathrm{CH}_{2} \mathrm{CH}_{2} \mathrm{OH}, 2 \mathrm{H}$ ), $\delta 1.45$ (quin, $\mathrm{CH}_{2}=\mathrm{CHCH}_{2} \mathrm{CH}_{2} \mathrm{CH}_{2} \mathrm{OH}, 2 \mathrm{H}$ ). 
(h) 3-penten-1-ol: (mixture of isomers): $\delta 5.41$ (m, $\left.\mathrm{CH}_{3} \mathrm{CH}=\mathrm{CHCH}_{2} \mathrm{CH}_{2} \mathrm{OH}, 1 \mathrm{H}\right), \delta 5.25$ (m, $\left.\mathrm{CH}_{3} \mathrm{CH}=\mathrm{CHCH}_{2} \mathrm{CH}_{2} \mathrm{OH}, 1 \mathrm{H}\right), \delta 3.42\left(\mathrm{t}, \mathrm{CH}_{3} \mathrm{CH}=\mathrm{CHCH}_{2} \mathrm{CH}_{2} \mathrm{OH}, 2 \mathrm{H}\right), \delta 1.91(\mathrm{q}$, $\left.\mathrm{CH}_{3} \mathrm{CH}=\mathrm{CHCH}_{2} \mathrm{CH}_{2} \mathrm{OH}, 2 \mathrm{H}\right), \delta 1.44\left(\mathrm{~d}, \mathrm{CH}_{3} \mathrm{CH}=\mathrm{CHCH}_{2} \mathrm{CH}_{2} \mathrm{OH}, 3 \mathrm{H}\right)$.

(i) 5-hydroxy-pentan-2-one: $\delta 3.41\left(\mathrm{t}, \mathrm{CH}_{3} \mathrm{C}(\mathrm{O}) \mathrm{CH}_{2} \mathrm{CH}_{2} \mathrm{CH}_{2} \mathrm{OH}, 2 \mathrm{H}\right), \delta 2.42$ (t, $\mathrm{CH}_{3} \mathrm{C}(\mathrm{O}) \mathrm{CH}_{2} \mathrm{CH}_{2} \mathrm{CH}_{2} \mathrm{OH}, 2 \mathrm{H}$ ), $\delta 2.01\left(\mathrm{~s}, \mathrm{CH}_{3} \mathrm{C}(\mathrm{O}) \mathrm{CH}_{2} \mathrm{CH}_{2} \mathrm{CH}_{2} \mathrm{OH}, 3 \mathrm{H}\right.$ ), $\delta 1.55$ (quin, $\left.\mathrm{CH}_{3} \mathrm{C}(\mathrm{O}) \mathrm{CH}_{2} \mathrm{CH}_{2} \mathrm{CH}_{2} \mathrm{OH}, 2 \mathrm{H}\right)$.

(j) 1-penten-3-ol: $\delta 5.61\left(\mathrm{~m}, \mathrm{CH}_{2}=\mathrm{CHCHOHCH}_{2} \mathrm{CH}_{3}, 1 \mathrm{H}\right), \delta 4.95(\mathrm{~m}$, $\mathrm{CH}_{2}=\mathrm{CHCHOHCH}_{2} \mathrm{CH}_{3}, 2 \mathrm{H}$ ), $\delta 3.84$ (q, $\mathrm{CH}_{2}=\mathrm{CHCHOHCH}_{2} \mathrm{CH}_{3}, 1 \mathrm{H}$ ), $\delta 1.29$ (quin, $\left.\mathrm{CH}_{2}=\mathrm{CHCHOHCH}_{2} \mathrm{CH}_{3}, 2 \mathrm{H}\right), \delta 0.71\left(\mathrm{t}, \mathrm{CH}_{2}=\mathrm{CHCHOHCH}_{2} \mathrm{CH}_{3}, 3 \mathrm{H}\right)$.

(k) 4-penten-2-ol: $\delta 5.56\left(\mathrm{~m}, \mathrm{CH}_{2}=\mathrm{CHCH}_{2} \mathrm{CHOHCH}_{3}, 1 \mathrm{H}\right), \delta 4.91(\mathrm{~m}$, $\left.\mathrm{CH}_{2}=\mathrm{CHCH}_{2} \mathrm{CHOHCH}_{3}, 2 \mathrm{H}\right), \delta 3.74\left(\mathrm{~m}, \mathrm{CH}_{2}=\mathrm{CHCH}_{2} \mathrm{CHOHCH}_{3}, 1 \mathrm{H}\right), \delta 2.04$ (br, $\left.\mathrm{CH}_{2}=\mathrm{CHCH}_{2} \mathrm{CHOHCH}_{3}, 2 \mathrm{H}\right), \delta 0.96\left(\mathrm{~d}, \mathrm{CH}_{2}=\mathrm{CHCH}_{2} \mathrm{CHOHCH}_{3}, 3 \mathrm{H}\right)$.

(l) 3-penten-2-ol: $\delta 5.49$ (m, $\left.\mathrm{CH}_{3} \mathrm{CH}=\mathrm{CHCHOHCH}_{3}, 1 \mathrm{H}\right), \delta 5.34$ (m, $\mathrm{CH}_{3} \mathrm{CH}=\mathrm{CHCHOHCH}, 1 \mathrm{H}$ ), $\delta 3.95$ (quin, $\mathrm{CH}_{3} \mathrm{CH}=\mathrm{CHCHOHCH}_{3}, 1 \mathrm{H}$ ), $\delta 1.45$ (d, $\left.\mathrm{CH}_{3} \mathrm{CH}=\mathrm{CHCHOHCH} 3,3 \mathrm{H}\right), \delta 0.99\left(\mathrm{~d}, \mathrm{CH}_{3} \mathrm{CH}=\mathrm{CHCHOHCH}_{3}, 3 \mathrm{H}\right)$.

Reaction of cis-Pt(Cl $)_{2}$ (TPPTS $)_{2}$ with an excess of allyl alcohol at $80{ }^{\circ} \mathrm{C}$, resulted in the formation of a product characterized by a ${ }^{31} \mathrm{P}$ resonance at $\delta 18.9 \mathrm{ppm}$ with ${ }^{1} \mathrm{~J}_{\mathrm{Pt}-\mathrm{P}}=4014 \mathrm{~Hz}$ in the ${ }^{31} \mathrm{P}$ NMR spectrum. The $\mathrm{pH}$ of the solution changed from $\sim 3$ to $\sim 2$. Due to the large excess of allyl alcohol used, detailed analysis of the ${ }^{1} \mathrm{H}$ NMR spectrum was difficult. The ${ }^{195} \mathrm{Pt}$ NMR spectrum showed a triplet at $\delta-5391 \mathrm{ppm}$ with ${ }^{1} \mathrm{~J}_{\mathrm{Pt}-\mathrm{P}}=4014 \mathrm{~Hz}$, as shown in Table 1. A large scale synthesis used $\mathrm{PtCl}_{2}$ and 2 equiv. of TPPTS in water at $70{ }^{\circ} \mathrm{C}$. Upon complete dissolution of the $\mathrm{PtCl}_{2}$, excess allyl alcohol was added to the reaction mixture, which was allowed to stir at 
the above temperature for $15 \mathrm{~h}$. The final product was precipitated by the addition of EtOH and collected. The ${ }^{31} \mathrm{P}$ NMR spectrum showed the same signal as above in $~ 90 \%$ yield, along with some unreacted cis-Pt(Cl) $)_{2}(\mathrm{TPPTS})_{2}$. The ${ }^{1} \mathrm{H}$ NMR spectrum showed the following resonances (excluding aromatic and solvent protons): $\delta 5.47(\mathrm{~m}, 1 \mathrm{H}), \delta 3.90(\mathrm{br}, 2 \mathrm{H})$, and $\delta 3.00(\mathrm{~m}, 2 \mathrm{H})$. A 2D ${ }^{1} \mathrm{H}$ COSY NMR was also taken which showed correlation between the resonance at $\delta 5.47$ and the other signals, although these two signals did not show any correlation to each other. Based on these results and those from the previous sample, we propose the formation of $\left[\operatorname{Pt}\left(\eta^{3}\right.\right.$ $\left.\left.\mathrm{C}_{3} \mathrm{H}_{5}\right)(\mathrm{TPPTS})_{2}\right]^{+}:(\mathrm{L}=\mathrm{TPPTS})$

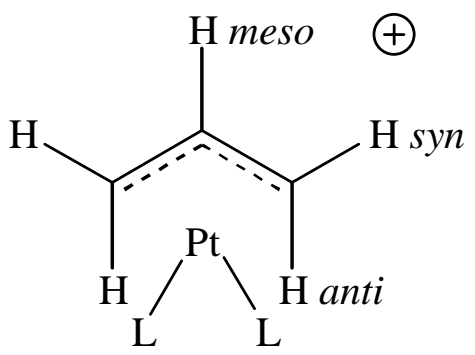

The phosphines in this molecule are equivalent and give a singlet in the ${ }^{31} \mathrm{P}$ NMR spectrum. Also, this equivalence would lead to a triplet in the ${ }^{195} \mathrm{Pt}$ NMR spectrum. The ${ }^{195} \mathrm{Pt}$ chemical shift is comparable to that of $\mathrm{Pt}($ allyl) 2 , which was found to be $\delta-5963 \mathrm{ppm}$ (taken in $\mathrm{d}_{8}$-THF at $\left.278 \mathrm{~K}\right){ }^{18}$ The ${ }^{1} \mathrm{H}$ NMR resonances nearly mirror those of the $\mathrm{PPh}_{3}$ analog taken at $50{ }^{\circ} \mathrm{C}$ in $\mathrm{CDCl}_{3}$, as shown in Table 2. As discussed above, the organic soluble compound undergoes interconversion between the $\eta^{3}$ - and $\eta^{1}$-conformations at higher temperatures. The presence of water as a solvent apparently slows the interconversion. Polar solvents are known to favor $\eta^{3}$-allyl complexes. ${ }^{4 a}$ A NMR spectrum was taken of our product at $5{ }^{\circ} \mathrm{C}$. The ${ }^{31} \mathrm{P}$ NMR spectrum was unchanged, while the resonances in the ${ }^{1} \mathrm{H}$ NMR spectrum sharpened slightly. Broadening of the ${ }^{1} \mathrm{H}$ resonances occurred on heating to $60{ }^{\circ} \mathrm{C}$. The COSY NMR results match 
this type of species since it is well known that no correlation is seen between the syn and anti protons of the allyl fragment. ${ }^{1 \mathrm{a}}$

A similar compound was produced from the reaction of cis-Pt(Cl $)_{2}(\mathrm{TPPTS})_{2}$ with 3buten-1-ol at $80{ }^{\circ} \mathrm{C}$. During the reaction the color of the solution changes from yellow to colorless. EtOH was added to the reaction mixture to precipitate the product, as well as to remove excess substrate so that analysis by ${ }^{1} \mathrm{H}$ NMR spectroscopy is feasible. Analysis by ${ }^{31} \mathrm{P}$ NMR spectroscopy revealed the complete conversion of the Pt starting material into the following signals (integration showed in parentheses):

$$
\begin{aligned}
& \delta 23.03\left(\mathrm{~d},{ }^{1} \mathrm{~J}_{\mathrm{Pt}-\mathrm{P}}=3951 \mathrm{~Hz},{ }^{2} \mathrm{~J}_{\mathrm{P}-\mathrm{P}}=7.1 \mathrm{~Hz}\right) \\
& \delta 19.37\left(\mathrm{~d},{ }^{1} \mathrm{~J}_{\mathrm{Pt}-\mathrm{P}}=4202 \mathrm{~Hz},{ }^{2} \mathrm{~J}_{\mathrm{P}-\mathrm{P}}=7.1 \mathrm{~Hz}\right)
\end{aligned}
$$

Based on the results from allyl alcohol, we believe that a similar $\operatorname{Pt}\left(\eta^{3}\right.$-allyl) compound was formed. The proposed structure of $\left[\mathrm{Pt}\left(\eta^{3}-\mathrm{C}_{4} \mathrm{H}_{7}\right)(\mathrm{TPPTS})_{2}\right]^{+}$is shown below:

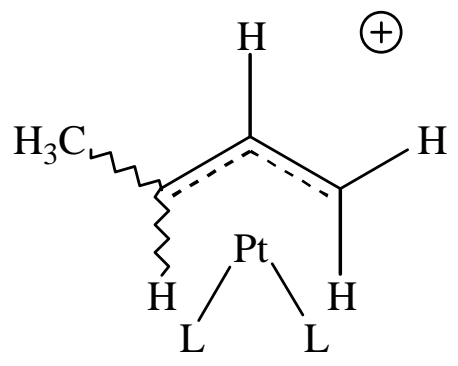

In this case, the allyl fragment will not be symmetric, thus causing inequivalence of the two phosphine ligands and two doublets in the ${ }^{31} \mathrm{P}$ NMR spectrum. In the results above, another set of doublets is present as well. The methyl group on the allyl fragment could lie in either the syn or anti position. Analysis of the solution by ${ }^{195} \mathrm{Pt}$ NMR spectroscopy showed the appearance two sets of doublets of doublets, the major set centered at $\delta-5379 \mathrm{ppm}$ with ${ }^{1} \mathrm{~J}_{\mathrm{Pt}-\mathrm{P}}=3951 \mathrm{~Hz}$ and 
$4202 \mathrm{~Hz}$ and the minor at $\delta-5363 \mathrm{ppm}$ with ${ }^{1} \mathrm{~J}_{\mathrm{Pt}-\mathrm{P}}=4059 \mathrm{~Hz}$ and $3888 \mathrm{~Hz}$. Analysis by ${ }^{1} \mathrm{H}$ NMR spectroscopy was difficult due to the presence of the two isomers plus other residual organic products formed in the reaction as shown in Figure S1. The resonances at $\delta 5.24(\mathrm{~m})$ and $\delta 5.44$ (m) are attributed to the meso protons on the two isomers. Therefore we employed $1 \mathrm{D}{ }^{1} \mathrm{H}$ TOCSY NMR analysis to aid in identifying the other resonances associated with the allyl compound. In this experiment, we pulsed the resonance at $\delta 5.24 \mathrm{ppm}$ as shown in Figure 1a; the result is shown in Figure 1b. From this we were able to identify the resonances for one isomer of the allyl. We then pulsed the resonance at $\delta 5.44$ in order to decipher the signals for $2^{\text {nd }}$ isomer as well. The results are shown in Table 2 along with that of the $\mathrm{PPh}_{3}$ analog. We were able to identify the separate isomers as syn and anti by comparison against these analogs, with the syn isomer dominant. According to the literature, the syn isomer is favored with less steric repulsion between the substituent and the metal, compared to the anti isomer. ${ }^{8}$

Similar behavior is seen in reaction of $c i s-\mathrm{Pt}(\mathrm{Cl})_{2}(\mathrm{TPPTS})_{2}$ with 4-penten-1-ol at $80{ }^{\circ} \mathrm{C}$ in water. Again, during the course of the reaction, the color of the solution changed from yellow to colorless. EtOH is used to precipitate the allyl compound from the reaction mixture. Five possible structures are possible for $\left[\mathrm{Pt}\left(\eta^{3}-\mathrm{C}_{5} \mathrm{H}_{9}\right)(\mathrm{TPPTS})_{2}\right]^{+}$, as shown in the scheme below:

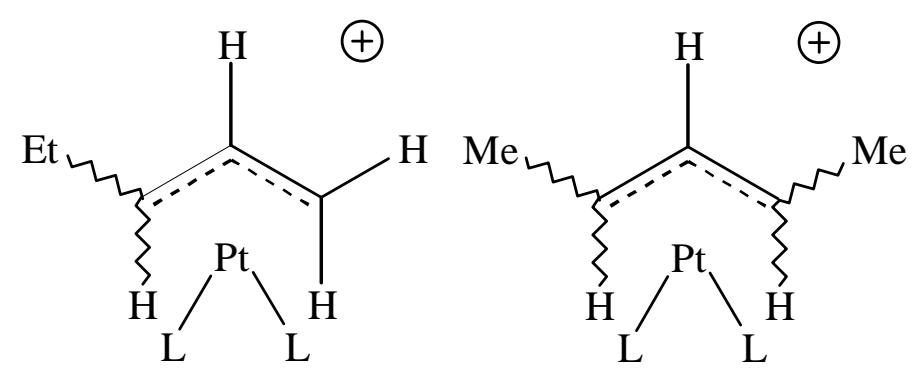

The first structure listed would yield syn and anti isomers, similar to those described above. Therefore, ${ }^{31} \mathrm{P}$ NMR spectra should show two sets of two doublets with similar coupling 
constants to the terminal methyl derivative above. The second structure listed would yield three isomers (syn/syn Me’s, anti/anti Me’s, or syn/anti Me’s). The two isomers with the methyls in the same location would show a singlet in the ${ }^{31} \mathrm{P}$ spectrum since a symmetrical allyl fragment would be produced. In the last case, the allyl fragment is again asymmetric resulting in inequivalent phosphines and thus a pair of doublets in the ${ }^{31} \mathrm{P}$ NMR spectrum, with differing coupling constants. ${ }^{31} \mathrm{P}$ NMR spectra revealed the presence of two sets of two doublets in a ratio of 70:30. As seen in Table 1 the coupling constants and chemical shifts nearly mirror those of the terminal methyl allyl compound. Therefore, we believe the major species to be the syn terminal ethyl allyl, while the minor is the anti isomer. The ${ }^{1} \mathrm{H}$ NMR resonances obtained as described above are listed in Table 2 with the $\mathrm{PPh}_{3}$ analogues.

So far, only terminal alkenes with the hydroxyl lying on the opposite end of the molecule have been utilized. Therefore we attempted the reaction of cis-Pt(Cl $)_{2}(\mathrm{TPPTS})_{2}$ with 4-penten-2ol in water at $80{ }^{\circ} \mathrm{C}$. The same color changes occur to the solution. Again, EtOH is added to precipitate the solid product. Analysis by ${ }^{31} \mathrm{P}$ NMR spectroscopy revealed the presence of two singlets and a pair of doublets.

$$
\begin{aligned}
& \delta 22.06\left(\mathrm{~s},{ }^{1} \mathrm{~J}_{\mathrm{Pt}-\mathrm{P}}=4109 \mathrm{~Hz}\right) \\
& \delta 21.36\left(\mathrm{~d},{ }^{1} \mathrm{~J}_{\mathrm{Pt}-\mathrm{P}}=3883 \mathrm{~Hz},{ }^{2} \mathrm{~J}_{\mathrm{P}-\mathrm{P}}=5.3 \mathrm{~Hz}\right) \\
& \delta 18.98\left(\mathrm{~d},{ }^{1} \mathrm{~J}_{\mathrm{Pt}-\mathrm{P}}=4143 \mathrm{~Hz},{ }^{2} \mathrm{~J}_{\mathrm{P}-\mathrm{P}}=5.3 \mathrm{~Hz}\right) \\
& \delta 18.36\left(\mathrm{~s},{ }^{1} \mathrm{~J}_{\mathrm{Pt}-\mathrm{P}}=4002 \mathrm{~Hz}\right)
\end{aligned}
$$

The coupling constants for the pair of doublets do not match those for the terminal ethyl allyl compound discussed above. Therefore, we believe that three isomers of the same compound are present: syn/syn Me’s, anti/anti Me’s, and syn/anti Me’s. The ${ }^{195} \mathrm{Pt}$ NMR spectrum of this mixture is shown in Figure 3. Simulated spectra of all three isomers were utilized in order to assign the resonances. The coupling constants and chemical shifts (Table 1) for the syn/syn and syn/anti isomers closely resemble those for the $\mathrm{PPh}_{3}$ analogues. The difference in formation of 
the allyl compounds from that of 4-penten-1-ol was thought to arise from migration of the double bond down the carbon chain. The hydroxyl group on the substrates plays a key role in the interaction with the Pt center and the double bond to form an allylic compound, thus the distance between this group and the double bond is very important. For example, in allyl alcohol, the double bond lies close to the hydroxyl group, while in 3-buten-1-ol and 4-penten-1-ol the double bond needs to migrate towards the hydroxyl group, thus producing a terminal allyl compound. However, in the case of 4-penten-2-ol, an internal allyl would be formed with terminal methyls resulting on each side of the allyl as shown below (black dot details location of where the Pt-allyl compound would be produced):

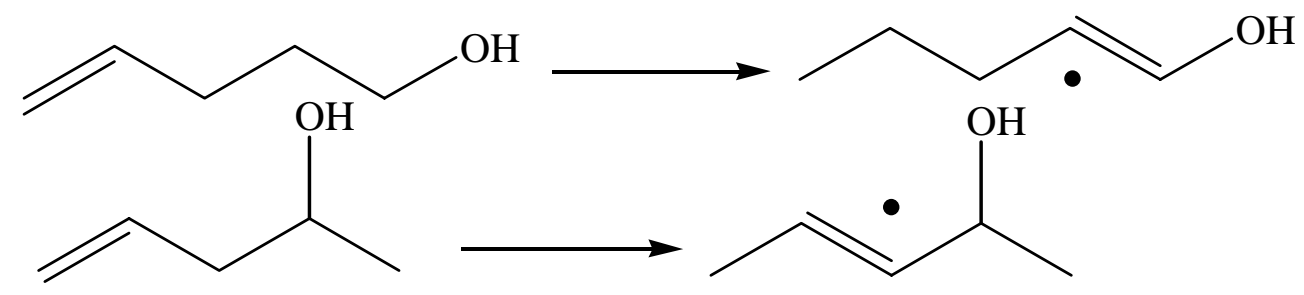

\section{Effect of Added Chloride}

To determine the effect of added chloride ion, cis-Pt(Cl $)_{2}(\mathrm{TPPTS})_{2}$ and excess 3-buten-1ol were dissolved in water containing 12 equiv (based on Pt complex) of $\mathrm{NaCl}$. After heating the reaction, ${ }^{31} \mathrm{P}$ NMR analysis showed only $17 \%$ conversion to syn and anti-[Pt $\left(\eta^{3}-\right.$ $\left.\left.\mathrm{C}_{4} \mathrm{H}_{7}\right)(\text { TPPTS })_{2}\right]^{+}$. Without the added chloride, full conversion was always seen. Thus, the presence of chloride inhibits reaction of the Pt compound with substrates. 


\section{Effect of Water}

To gain an understanding of the effect of water, the reactions of cis- $\mathrm{Pt}(\mathrm{Cl})_{2}\left(\mathrm{P}(p \text {-tolyl })_{3}\right)_{2}$ were examined in dry THF. Reaction of cis- $\left.\mathrm{Pt}(\mathrm{Cl})_{2}(p \text {-tolyl })_{3}\right)_{2}$ with 3-buten-1-ol at room temperature and at $60{ }^{\circ} \mathrm{C}$, showed no change in the Pt starting material or the substrate as determined by multinuclear NMR spectroscopy. To ascertain whether the role of water was to facilitate $\mathrm{Cl}^{-}$dissociation, we sought to remove one chloride from the starting Pt material by silver metathesis to give $\mathrm{Pt}(\mathrm{THF})(\mathrm{Cl})\left(\mathrm{P}(p \text {-tolyl })_{3}\right)_{2}{ }^{+}$. This material was reacted with excess 3buten-1-ol at $60{ }^{\circ} \mathrm{C}$ in dry THF. Once again, no change in either starting material was observed. Removal of both chlorides by silver metathesis resulted in the formation of $\left[\mathrm{Pt}(\mathrm{THF})_{2}(\mathrm{P}(p-\right.$ tolyl $\left.\left.)_{3}\right)_{2}\right]^{2+}$. Reaction of the substrate, under the same conditions as the monochloride species, resulted in no reaction. Thus water plays a key role in reaction of cis- $\mathrm{Pt}(\mathrm{Cl})_{2}(\mathrm{TPPTS})_{2}$ with the hydroxyl functionalized substrates to form $\mathrm{Pt}\left(\eta^{3}\right.$-allyl) species, more than facilitating $\mathrm{Cl}^{-}$ dissociation.

\section{Deuterium-Labeling Experiments}

A series of reactions were undertaken in order to determine the effect of $\mathrm{D}_{2} \mathrm{O}$. In the first set, cis- $\mathrm{Pt}(\mathrm{Cl})_{2}$ (TPPTS $)_{2}$ was reacted with 10 equiv. of allyl alcohol at $80{ }^{\circ} \mathrm{C}$ in $\mathrm{H}_{2} \mathrm{O}$ and in $\mathrm{D}_{2} \mathrm{O}$

for 3 h. ${ }^{31} \mathrm{P}$ NMR spectra showed complete conversion to $\left[\mathrm{Pt}\left(\eta^{3}-\mathrm{C}_{3} \mathrm{H}_{5}\right)(\mathrm{TPPTS})_{2}\right]^{+}$in both cases. In both cases, acetol was present in a stoichiometric ratio with the $\left[\operatorname{Pt}\left(\eta^{3} \text {-allyl }\right)(\mathrm{TPPTS})_{2}\right]^{+}$. In $\mathrm{H}_{2} \mathrm{O}$, the integration between the signals ( $\delta 4.21$ (s) and $\delta 2.01(\mathrm{~s})$ ) was $2: 3$, while in $\mathrm{D}_{2} \mathrm{O}$ the integration was 2:2 and the singlet at $\delta 2.01$ was replaced by a broad resonance. These experiments indicate monodeuteration of the methyl group of the acetol. A set of similar reactions with 3-buten-1-ol showed full conversion to syn and anti-[Pt( $\left.\left(\eta^{3}-\mathrm{C}_{4} \mathrm{H}_{7}\right)(\mathrm{TPPTS})_{2}\right]^{+}$. 
Shown in Figure S2 are the resulting ${ }^{1} \mathrm{H}$ NMR spectra of the (a) $\mathrm{H}_{2} \mathrm{O}$ and the (b) $\mathrm{D}_{2} \mathrm{O}$ solution. In the case of this substrate, catalytic conversion to 4-hydroxy-butan-2-one was noted. Since deuterium has a weak quadrupole moment, the neighboring protons will exhibit coupling to this nucleus. ${ }^{\mathrm{S} 1}$ The coupling constant has been found to be $\mathrm{J}_{\mathrm{H}-\mathrm{D}} / \mathrm{J}_{\mathrm{H}-\mathrm{H}}=6.514 .{ }^{\mathrm{S} 2}$ Thus, monodeuteration of nitromethane resulted in the appearance of a 1/1/1 triplet, while dideuteration gives a 1/2/3/2/1 quintet. ${ }^{\mathrm{S} 1}$ As seen in Figure S2(b), a 1/1/1 triplet is definitely present, supporting monodeuteration.

Since the reaction of cis-Pt(Cl $)_{2}(\mathrm{TPPTS})_{2}$ with 4-penten-1-ol at room temperature showed the most conversion to 3-penten-1-ol, we decided to determine if deuterium incorporation was occurring into the isomerization products. Therefore two reactions were set-up in which 20 equiv. of 4-penten-1-ol was added to either a $\mathrm{H}_{2} \mathrm{O}$ or $\mathrm{D}_{2} \mathrm{O}$ solution of $c$ cis- $\mathrm{Pt}(\mathrm{Cl})_{2}(\mathrm{TPPTS})_{2}$. ${ }^{31} \mathrm{P}$ NMR spectra showed roughly the same conversion to the allyl species already discussed. The ${ }^{1} \mathrm{H}$ NMR spectra once again showed that the Wacker oxidation product 5-hydroxy-pentan-2-one, contained monodeuteration at the terminal methyl position in the $\mathrm{D}_{2} \mathrm{O}$ solution. However, incorporation was not seen into the isomerization product, 3-penten-1-ol. 


\section{References for Supporting Information}

S1. Lambert, J. B.; Shurvell, H. F.; Lightner, D. A.; Cooks, R. G., Organic Structural Analysis, Prentice Hall, NJ, 1998, p. 93.

S2. Gordon, A. J.; Ford, R. A., Chemist's Companion, Wiley Interscience, NY, 1972, p. 220. 


\section{Supporting Figure Captions}

Figure S1: Resulting ${ }^{1} \mathrm{H}$ NMR spectrum from reaction of cis-Pt(Cl $)_{2}(\mathrm{TPPTS})_{2}$ with 3-buten-1ol, after precipitation with EtOH and dissolution in $\mathrm{D}_{2} \mathrm{O}$.

Figure S2: Resulting ${ }^{1} \mathrm{H}$ NMR spectra of the terminal methyl group of 4-hydroxy-butan-2-one from reaction of cis- $\mathrm{Pt}(\mathrm{Cl})_{2}$ (TPPTS $)_{2}$ with 3-buten-1-ol in (a) $\mathrm{H}_{2} \mathrm{O}$ and (b) $\mathrm{D}_{2} \mathrm{O}$. Monodeuteration of this group at 2.05 is clearly seen in (b). 


$$
\text { يالبليل. }
$$




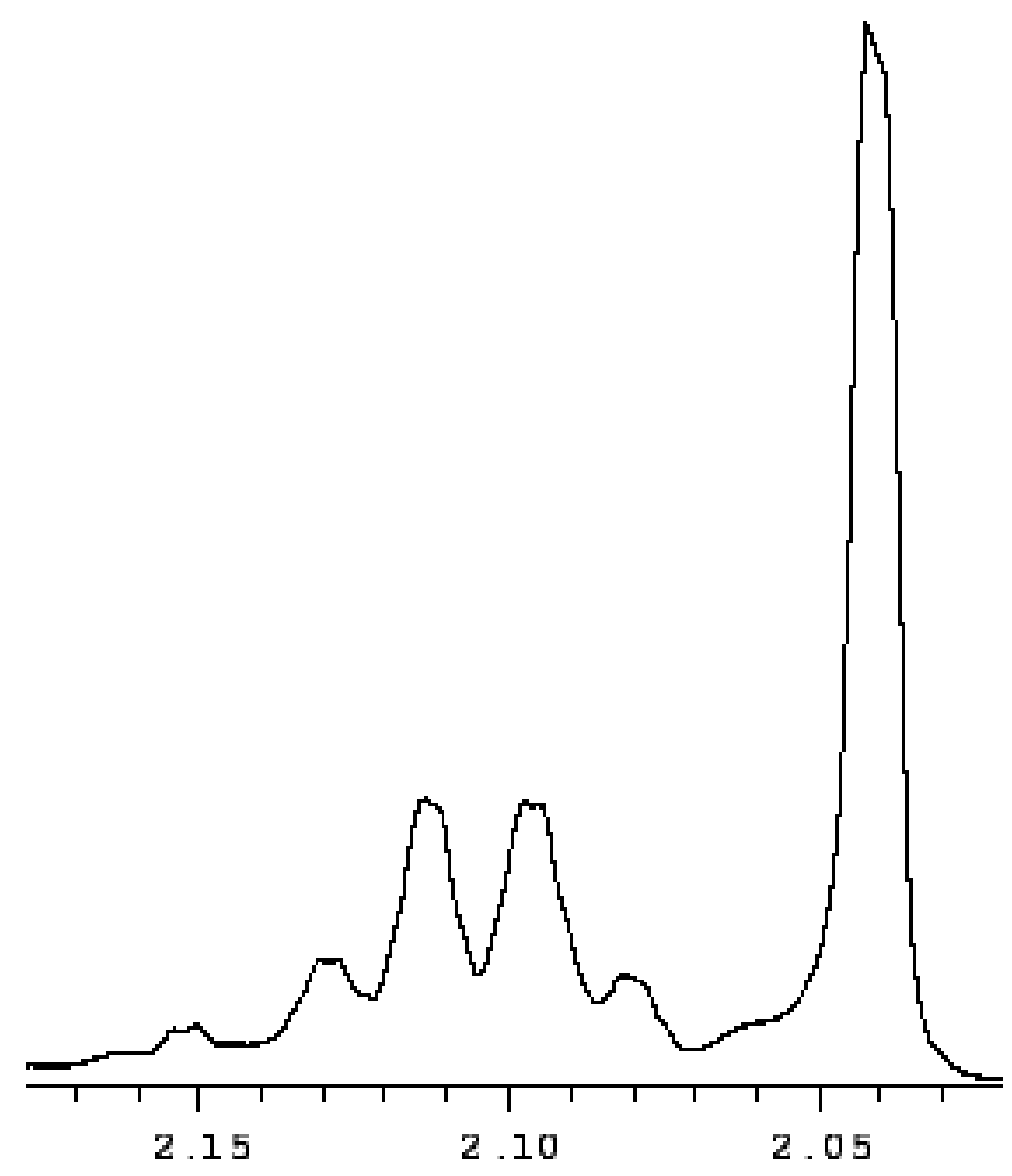

(a)

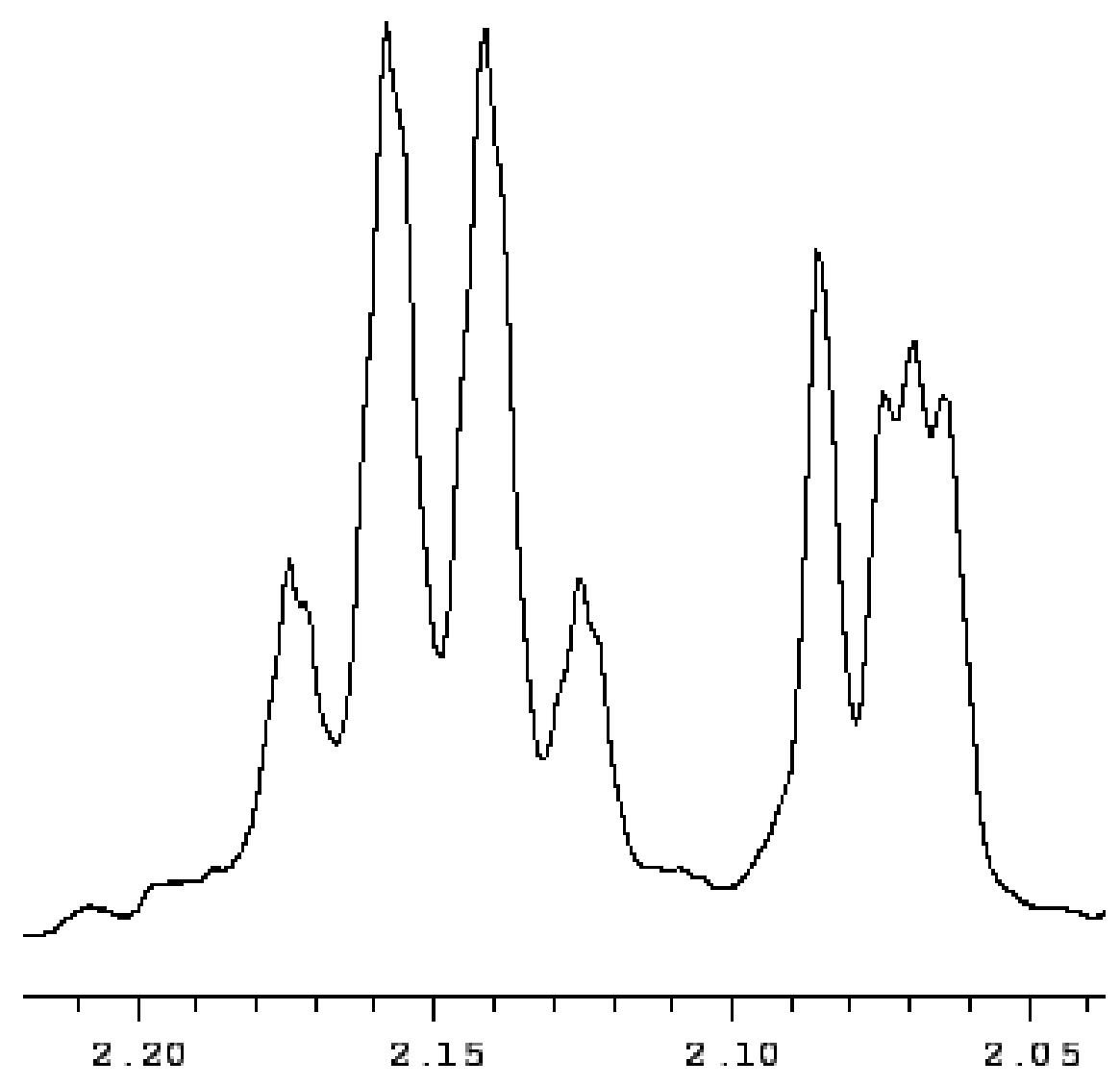

(b) 